\title{
Destek Eğitim Odası Hizmetine İlişkin Görüşlere Odaklanan Lisansüstü Tezlerin Sistematik İncelemesi \\ Ercan ÖPENGIN*
}

Öz: Türkiye’de son y1llarda özel eğitimde önemli bir işleve sahip olan destek eğitim odası hizmetine odaklanan araştırmaların sayısında artış görülmektedir. Bu araştırmanın amacı, destek eğitim odası hizmetine ilişkin katılımcı görüşlerini konu edinen ve eğitim bilimleri alanında hazırlanan lisansüstü tezlerinin incelenmesidir. Bu amaçla 12 lisansüstü teze odaklanılmıştır. Çalışma, Türkiye'de gerçekleştirilen nitel veri toplama tekniklerinden görüşmelerin kullanıldığ 1 araştırmaları derinlemesine incelemek amacıyla sistematik derleme şeklinde desenlenmiştir. Çalışmaların incelenmesinde karşılaştırmalı ve keşfedici bir analiz süreci gerçekleştirilmiştir. Analizler sonucunda üç ana kategori ortaya çıkmıştır. Bunlar; DEO hizmetinin mevcut durumu, karşılaşılan sorunlar ve DEO hizmetinin niteliğini arttırmaya yönelik önerilerdir. Bu kategorilerin altında fiziksel koşullar, verilen eğitim, planlama, tutum ve materyal alt kategorileri yer almıştır. Yapılan analiz sonucunda destek eğitim odası hizmetinin niteliğinin artırılmasına ilişsin olarak gelişim odaklı araştırmaların gerçekleştirilmesi gerektiği söylenebilir.

Anahtar Kelimeler: Destek eğitim odası hizmeti, Lisansüstü tezler, Nitel araştırma, Sistematik değerlendirme.

\section{A Systematic Analysis of Theses Focusing on Views Related to Resource Room}

Abstract: In Turkey, the number of research focusing on resource rooms which have an important function in special education seems to increase in recent years. The aim of this study is to examine the postgraduate theses in which the opinions of the participants about the resource room are evaluated. For this purpose, twelve researches were focused. The study designed as a systematic review in order to analyze in depth the postgraduate theses conducted in Turkey employing interviews, one of the qualitative data collection techniques. A comparative and exploratory analysis process has been carried out in terms of revealing the studies. Accordingly, three main categories have been emerged. These are current situation of

*Dr. Öğretim Üyesi, Van YYÜ, Eğitim Fakültesi, Özel Eğitim Bölümü, Email:ercanopengin@yyu.edu.tr , Orcid No: 00000001-9526-4313 
resource rooms, problems regarding resource rooms, and suggestions to increase the quality of resource rooms. Additionally, five subcategories named as physical conditions, education, planning, attitude and material have been found. Based on the findings of the research, it can be said that development-oriented studies should be carried out on resource rooms.

Keywords: Resource room, Postgraduate theses, Qualitative studies, Systematic review

\section{Giriş}

Okullarda eğitim faaliyetleri, genellikle aynı yaş grubunda olan bütün öğrencilerin benzer zihinsel kapasiteye sahip olduğu düşüncesine göre kurgulanmaktadır (Osin ve Lesgold, 1996). Bunun sonucu olarak geliştirilen program ve eğitim materyallerinin çoğunluğu “ortalama” öğrencilere göre hazırlanmaktadır (Rogers, 2002). Böyle kurgulanmış bir sistemde bazı öğrenciler ortalamanın gerisinde olmalarından, bazıları da ortalamanın üstünde olmalarından dolayı olumsuz etkilenmektedir (van der Meulen, van der Bruggen, Spilt, Verouden, Berkhout ve Bögels, 2014). Her ne kadar normal gelişim gösteren çoğu öğrencinin akademik gereksinimleri birbirlerine yakın olsa da akademik gelişimleri farklılık gösterenlerin eğitim gereksinimleri de farklılaşmaktadır (Mengi, 2020). Genel olarak öğrenciler arasındaki benzerlikler, farklılıklarından fazladır. Fakat aralarında var olan bilişsel gelişim düzeyi veya çeşitli fiziksel farklılıklar, bazı öğrencilerin sunulan genel eğitimden uygun şekilde yararlanmalarına olanak vermeyebilir. Bu doğrultuda özel öğrenme güçlüğü yaşayan veya herhangi bir yetersizliği olan öğrenciler için söz konusu eğitim sisteminde uyarlamalar ve düzenlemelerin yapılması veya özel eğitim hizmetinin sunulması gerektiğine dair açıklamalar bulunmaktadir (Heward, 2013).

Tarihsel süreç içerisinde farklı gelişim gösteren bireylerin eğitimine ilişkin düşünceler, eğitim alamayacaklarından sırasıyla ayrı eğitim ve günümüzde bütünleşik eğitime evrilmiştir. Böylece zamanla bu bireylerin eğitimine ilişkin düşünceler olumlu yönde gelişerek ilerlemiştir. Özel gereksinimli öğrenciler için en uygun eğitimin akranlarıyla aynı sınıfta, hiçbir ayrımcılığa uğramadan ve gereksinimleri doğrultusunda destek eğitim hizmetlerinin sunulduğu kaynaştırma/bütünleştirme eğitimi uygulaması olduğu genel kabul görmektedir (Farrell, 2010; Güven, 2021; Yazıcıoğlu, 2018). Modern dünyadaki gelişmelere paralel olarak Türkiye'de de son yıllarda özel gereksinimli öğrencilerin normal gelişim gösteren akranları ile birlikte ve genel eğitim ortamlarında bulunmalarının önemi artmış ve eğitim sistemi bu yönde yapılandırılmıştır.

Türkiye'de kaynaştırma eğitimi tam veya yarı zamanlı olarak sürdürülmektedir. Tam zamanlı kaynaştırmanın verildiği okullarda eğitim ortamı olarak sıklıkla destek eğitim odası 
(DEO) kullanılmaktadır. Alanyazında kaynak oda adıyla da anılan DEO en geniş anlamda bir sınıf dışı eğitim hizmeti (pull-out) olarak kabul edilmektedir (Friend ve Bursuck, 2012; Gubbins, 2013; Heward, 2013). Türkiye'de resmi belgelerde son yıllarda kaynak oda yerine sadece destek eğitim odası terimi kullanılmaktadır. Özel Eğitim Hizmetleri Yönetmeliği’nde (2020) DEO “Tam zamanlı kaynaştırma/bütünleştirme yoluyla eğitimlerine devam eden öğrenciler ile özel yetenekli öğrencilere ihtiyaç duydukları alanlarda destek eğitim hizmetleri verilmesi için düzenlenmiş ortam olarak tanımlanmaktadır.” Bu tanımlamadan hareketle DEO’na devam eden öğrenciler, genel eğitim sınıflarına kayıtlı olmakla beraber, haftada belirli sürelerde okulda farklı bir sınıf ortamında (DEO) bireysel gereksinimleri doğrultusunda planlanmış bireysel veya küçük gruplar ile destek eğitimi almaktadırlar (Cox ve Daniel, 1984; Güven, 2021; Rogers, 2002).

Milli Eğitim Bakanlığı (MEB) tarafından yayınlanan 2015/15 nolu Genelge ve Özel Eğitim Hizmetleri Yönetmeliği gereğince, okul ve kurumlarda özel eğitime ihtiyacı olan öğrenciler ile özel yetenekli öğrenciler için gerekli düzenlemeler yapılarak DEO’ların açılması zorunlu hale gelmiştir. Bu zorunluluk ve özellikle son yıllarda özel gereksinimli öğrencilerin kaynaştırma eğitimine yönlendirilmesinin teşviki ile okullarda bu öğrenciler için açılan DEO’ların sayısının arttığı görülmektedir. Açılan DEO sayısındaki artışa paralel olarak niteliklerinin arttırılmasına da çalışılmaktadır. Nitekim daha önce sadece 33 ilde bulunan MEB tarafindan tasarlanan yeni standartlarda 79 tane DEO var iken, 2019' da 200 sayısına ve 2020'de ise her ilde en az bir tane olmak üzere toplamda 400 sayısına ulaşmıştır. (Hürriyet, 2020, 23 Ocak).

Özel gereksinimli öğrencilerin eğitiminde DEO hizmetinin yaygınlaşması, konuya ilişkin yapılan akademik çalışmaların sayısını da arttırmıştır. Son yıllarda Türkiye'de DEO'ları konu alan tez ve makalelerin sayısında (Akay, 2015; Akay ve Gürgür, 2018; Bedur, Bilgiç ve Taşlıdere, 2015; Çağlar, 2016; Çevik ve Yağcı, 2017; Demir ve Avcı, 2018; Dinçer ve Tortop, 2016; Kale ve Demir, 2017; Nar ve Tortop, 2017; Pemik, 2017; Tunal1-Erkan, 2018; Yazıcıŏlu, 2020) dikkat çekici bir artış gözlenmektedir. Konuya ilişsin çok fazla araştırmanın yapılmış olması, bu araştırmaların bütüncül bir bakış açısıyla değerlendirme ihtiyacını ortaya çıkarmıştır. Kaynaştırma/ bütünleştirme üzerine bütüncül değerlendirme araştırmaları hem uluslararası (Avramidis ve Norwich, 2002; DePape ve Lindsay, 2016) hem de ulusal ( Batu, Cüre, Nar, Gövercin ve Keskin, 2018; Deniz ve Çoban, 2019; Eripek, 2004; Gürgür ve Hasanoğlu-Yazçayır, 2019; Metin, 2013; Sucuoglu, 2004) alanyazında görülmektedir. Türkiye'de yapılan bütüncül araştırmalarda çeşitli sınırlamalara gidilmiştir. Örneğin Eripek 
(2004) 1984-2004 yılları arasında zihin engellilere yönelik araştırmaları konu edinirken, Sucuoğlu (2004) 1980-2005 yılları arasında kaynaştırma eğitimi üzerine yapılmış yayınları incelemiştir. Öte yandan Bakkaloğlu, Yılmaz, Altun Könez ve Yalçın, (2018) ve Metin (2013) sadece okulöncesi dönem üzerine yapılmış araştırmaları değerlendirmeye alırken, Batu v.d., (2018) ilk ve ortaokul düzeyinde yapılmış araştırmaları incelemişlerdir. Gürgür ve Hasanoğlu -Yazçayır (2019) ile Deniz ve Çoban (2019) ise kaynaştırma üzerine yapılmış ve öğretmen görüşlerini konu edinen araştırmaları sistematik olarak incelemişlerdir.

Türkiye'de yukarıda da görüldüğü gibi kaynaştırma/bütünleştirme üzerine yapılan çalışmaların incelendiği araştırmalara sıklıkla rastlanmaktadır. Fakat hem özel eğitimde artan sayıları ve işlevleri hem de son yıllarda hakkında yapılan araştırmaların çokluğuna rağmen DEO hizmeti üzerine bu tarz bütüncül incelemelerin yapıldığı araştırma bulunmamaktadır. DEO hizmeti üzerine yapılmış araştırmaların incelenmesi, şimdiye kadar konu ile ilgili yapılmış araştırmalara ilişskin kapsamlı bilgiye ulaşılmasına katkı sunacaktır. Ayrıca bu tarz araştırmaların, özellikle özel eğitime yönelik politika üreten başta MEB olmak üzere ilgili kurumlara ve bu alanda çalışan akademisyen ve öğretmenlere DEO hizmetine yönelik eksiklikler ve yapılması gerekenler konusunda perspektif sunması beklenmektedir. Araştırma DEO hizmetine yönelik farklı grupların görüşlerini konu edinen çalışmalarla sınırlandırılmıştır. Alanyazında DEO ve benzeri hizmetlere ilişkin paydaş görüşlerinin bilinmesinin önemini vurgulayan araştırmalar dikkat çekmektedir (Matthews ve Kitchen, 2007; Mittler, 2000). Bu hizmetlerin özellikle öğrencilere yönelik faydalarının değerlendirmesinde öğretmen, öğrenci, veli ve okul yöneticilerinin değerlendirmeleri, hizmetlerin etkisine dair önemli bilgiler sağlamaktadır. Ayrıca DEO hizmetine yönelik paydaş görüşlerine dair araştırmalara bir bütün olarak bakılması ve derinlemesine incelenmesi, yeni politikaların oluşturulmasında, konuya ilişkin yapılacak düzenlemelerde ve araştırmalarda yol gösterici olacağı düşünülmektedir. $\mathrm{Bu}$ düşüncelerden hareketle araştırmanın amacı, okullarda özel gereksinimli öğrencilere sunulan DEO hizmetine ilişkin paydaş görüşlerini konu edinen lisansüstü tezlerinin incelenmesidir.

\section{Yöntem}

$\mathrm{Bu}$ araştırma sistematik bir derleme olarak DEO hizmetine ilişkin görüşleri ortaya koyan eğitim bilimleri alanında yapılan lisansüstü tezlerin incelenmesi amacıyla gerçekleştirilmiştir. Bu bağlamda nitel araştırma yaklaşımına dayalı bir doküman analizi çalışmasıdır. Sistematik derleme; aynı konuda yapılmış olan araştırma sonuçlarını sentezlemek ve özetlemek için geliştirilmiş bir araştırma yöntemidir (Gökdemir ve Dolgun, 2020). Sistematik derleme çalışmalarında karmaşık, dağınık ya da çelişkili görünen sonuçlardan daha basit, anlamlı, derli 
toplu ve uygulanabilir sonuçlar elde etmek amaçlanmaktadır (Yılmaz, 2021). Bu araştırmada da özellikle DEO hizmetine ilişkin paydaş görüşlerine ilişkin çalışmaların bulgularının sentezlenmesi ve bütüncül bir yaklaşımla elde edilen sonuçların ortaya konması hedeflenmiştir. $\mathrm{Bu}$ sayede ilgili araştırmacılara, sistematik derlemelerin temel amaçları arasında da yer alan benzer çalışmalardan kaçınarak yeni fikirlerin üretilmesi (Creswell, 2014; Gay, Mills ve Airasian, 2006) konusunda destek sunması beklenmektedir.

\section{Araştırma Süreci}

$\mathrm{Bu}$ çalışmada sürecin, araştırmacının destek eğitim odası üzerine akademik araştırmaları incelemesi ile başladığı söylenebilir. Araştırmacı okumaları sürecinde DEO hizmetine ilişkin farklı paydaş gruplarının görüşlerine dayalı araştırmaların yoğun şekilde yapıldığını belirlemiştir. Buradan hareketle, yapılan çalışmalarda ortaya çıkan bulguların bütüncül bir bakışla sunulmasının alanyazına katkı sunacağı düşüncesiyle bu araştırmayı yapmaya karar vermiştir. Alanyazın taraması sürecinde destek eğitim odası üzerine görüşlere dayalı makalelerin genellikle lisansüstü tezlerden üretilmiş olmasından dolayı, araştırmayı eğitim bilimleri alanında yapılan lisansüstü tezler ile sınırlandırmaya karar vermiştir. Araştırmacı tarafından Yüksek Öğretim Kurulu (YÖK) Ulusal Tez Tarama Merkezi veri tabanında yüksek lisans ve doktora tezleri, belirlenen anahtar terim olan "destek eğitim odası" doğrultusunda listelenmiş ve 36 yüksek lisans ve doktora tezine ulaşılmıştır. Ulaşılan bu tezlerin yıllara göre dağılımı Tablo 1'de gösterilmiştir.

Tablo 1. Destek Eğitim Odası Konulu Lisansüstü Tezlerin Yıllara Göre Dağılımı

\begin{tabular}{lll}
\hline Yllar & Frekans & Yüzde \% \\
\hline 2008 & 1 & 3 \\
2011 & 2 & 6 \\
2012 & 2 & 6 \\
2013 & 1 & 3 \\
2015 & 2 & 6 \\
2016 & 3 & 8 \\
2017 & 5 & 14 \\
2018 & 3 & 8 \\
2019 & 15 & 42 \\
2020 & 2 & 6 \\
\hline
\end{tabular}

Tez merkezinden alınan 36 tez arasından bu çalışmanın amacına hizmet edebilecek araştırmaları belirlemek için nitel desenlenen araştırmaların ayıklanması sürecine gidilmiştir. Ayıklama süreci ile ilgili olarak aşağıdaki Tablo 2'de kaynaştırma eğitimi konulu 36 tane lisansüstü tezin yöntemsel bakımdan sınıflandırılması gösterilmektedir. 
Tablo 2. Destek Eğitim Odası Konulu Lisansüstü Tezlerinde Kullanılan Yöntemler

\begin{tabular}{lll}
\hline Yöntem & Frekans & Yüzde \\
\hline Nitel & 16 & 44 \\
Nicel & 12 & 33 \\
Karma & 3 & 8 \\
Değerlendirme & 1 & 3 \\
Eylem Araştırması & 4 & 11 \\
\hline
\end{tabular}

Belirlenen bu tezlerden sadece DEO hizmetine yönelik paydaş görüşlerini konu edinenler çalışma kapsamına alınmıştır. Bu araştırmanın amacına uygun, verilerin görüşme ile toplandığı nitel araştırma deseni kullanarak hazırlanmış 12 lisansüstü teze ilişkin bilgiler Tablo 3'te yer almaktadır.

Tablo 3. Çalışmaların Kapsamına ilişkin Bilgiler

\begin{tabular}{|c|c|c|c|c|c|}
\hline $\begin{array}{l}\text { Araştırma } \\
\text { Kodu }\end{array}$ & Yazar & Konu & $\begin{array}{l}\text { Araştırma } \\
\text { Deseni }\end{array}$ & $\begin{array}{l}\text { Veri } \\
\text { toplama } \\
\text { yöntemi }\end{array}$ & Katılımcılar \\
\hline A1 & Kış (2013) & $\begin{array}{l}\text { DEO’ya ilişkin } \\
\text { öğretmen görüşleri }\end{array}$ & Nitel araştırma & Görüşme & $\begin{array}{l}10 \text { Rehber Öğretmen } \\
10 \text { Özel eğitim öğretmeni }\end{array}$ \\
\hline A2 & Aydin (2015) & $\begin{array}{l}\text { DEO'ya ilişkin } \\
\text { öğretmen görüşleri }\end{array}$ & Nitel araştırma & Görüşme & 10 Sınıf öğretmeni \\
\hline A3 & Çağlar (2017) & $\begin{array}{l}\text { DEO’ya ilişkin } \\
\text { paydaş görüşleri }\end{array}$ & Fenomenoloji & Görüşme & 5 Yönetici, 18 Öğretmen \\
\hline A4 & Nar (2017) & $\begin{array}{l}\text { DEO'ya iliş̧kin } \\
\text { öğretmen görüşleri }\end{array}$ & Karma desen & Görüşme & 23 Sınıf öğretmeni \\
\hline A5 & Pemik (2017) & $\begin{array}{l}\text { DEO'ya ilişkin } \\
\text { paydaş görüşleri }\end{array}$ & Fenomenoloji & Görüşme & 20 Yönetici, 19 Öğretmen \\
\hline A6 & Semiz (2018) & $\begin{array}{l}\text { DEO'ya ilişkin } \\
\text { paydaş görüşleri }\end{array}$ & Nitel araştırma & Görüşme & 26 Öğretmen, 8 Veli \\
\hline A7 & Tamas (2019) & $\begin{array}{l}\text { DEO'ya ilişkin } \\
\text { paydaş görüşleri }\end{array}$ & Durum çalışması & Görüşme & 25 Öğretmen, 25 Veli \\
\hline A8 & Pesen (2019) & $\begin{array}{l}\text { DEO'ya ilişkin } \\
\text { öğretmen görüşleri }\end{array}$ & Karma desen & Görüşme & 60 Öğretmen \\
\hline A9 & Kaptan (2019) & $\begin{array}{l}\text { DEO’da } \\
\text { öğretmenlerin } \\
\text { karşılaştığı güçlükler }\end{array}$ & Nitel araştırma & Görüşme & 35 Öğretmen \\
\hline A10 & Dalga (2019) & $\begin{array}{l}\text { DEO'ya ilişkin } \\
\text { öğretmen görüşleri }\end{array}$ & Nitel araştırma & Görüşme & 15 Öğretmen \\
\hline A11 & Filik (2019) & $\begin{array}{l}\text { DEO’ya ilişkin } \\
\text { öğretmen görüşleri }\end{array}$ & Durum çalışması & Görüşme & 20 Öğretmen \\
\hline A12 & Aslan (2019) & $\begin{array}{l}\text { DEO’ya ilişkin } \\
\text { öğretmen görüşleri }\end{array}$ & Tarama & Görüşme & 35 Öğretmen \\
\hline
\end{tabular}

\section{Geçerlik ve Güvenirlik}

Nitel araştırmalarda, güvenirlik ve geçerlik kavramları yerine sağlamlık kavramı da kullanılmaktadır (Gürgür, 2017). Bu araştırmanın sağlamlığı için ise inandırıcılık, aktarılabirlik, tutarlılık ve onaylanabilirlik ölçütleri dikkate alınmıştır (Creswell, 2014). Bu doğrultuda araştırma verilerine kaynaklık eden çalışmaların belirlenme aşamaları ayrıntılı 
olarak açıklanmıştır. Seçilen araştırmaların bu çalışma kapsamına dahil olma ve olmama kriterleri sistematik olarak açıklanmıştır. Aktarılabilirlik için amaçlı örnekleme yapılmış ve ayrıntılı betimlemeler yapılmıştır. Bulunan temalara ulaşma süreci ayrıntılı olarak betimlenmiş, doğrudan alıntılar ile desteklenmiştir. Araştırmanın tüm adımları kolayca erişilebilir olması bakımından detaylı olarak rapor edilmiştir.

Araştırmaların bulguları içerik analizi ile incelenmiştir. Creswell'in (2014) belirttiği gibi nitel veriler incelenirken kullanılan araştırma desenine bağlı olarak farklı kodlama yöntemleri kullanılmaktadır. $\mathrm{Bu}$ çalışmada da incelenen lisansüstü tezlerin bulguları derinlemesine incelenerek temalara ulaşılmıştır. Analiz sürecinde, araştırmalara "A1, A2,....A13” gibi kod numaraları verilmiş, ve katılımcıların görüşlerini açık ve net bir şekilde yansıtabilmek amacıyla bulgular gerektiğinde doğrudan alıntılarla desteklenmiştir.

\section{Bulgular}

Türkiye' de destek eğitim odalarına ilişkin farklı paydaş gruplarının görüşlerine odaklı eğitim bilimleri alanında yapılan lisansüstü tezlerin incelenmesi sonucunda elde edilen bulgular belirli kategoriler altında sentezlenmiştir. Araştırma sürecinde lisansüstü tezlerin özellikle bulgular bölümleri detaylı incelenmiş ve gerçekleştirilen sentezleme çalışması sonunda 3 ana kategori ortaya çıkmıştır. Bunlar; DEO hizmetinde var olan durum, DEO hizmetinde yaşanan sorunlar ve DEO hizmetinde niteliği arttırmaya yönelik önerilerdir.

\section{DEO Hizmetinde Var Olan Durum}

Araştırma sürecinde incelenen lisansüstü tezlerin bulgularından, DEO hizmeti ile ilgili var olan duruma ilişkin elde edilen kategori ve alt kategoriler Tablo 4'de verilmiştir.

Tablo 4. DEO Hizmetinde Var Olan Duruma İlişkin Kategoriler

\begin{tabular}{lll}
\hline Kategori & Alt Kategori & İlgili Çalışma \\
\hline Fiziksel Koşullar & Fiziksel koşullar uygun & A2, A4 \\
& Fiziksel koşullar yetersiz & A5, A6, A7, A9, A10, A11, \\
\hline Verilen Eğitim & BEP & A1, A2, A6, A8, A12 \\
& Öğrenci gelişimi/ihtiyaç odaklı & A2, A3, A8, A11 \\
& Zekâ oyunları & A4, A5, \\
& Anlatıma dayalı & A6, A7, A8 \\
\hline Tutum & Öğrenci tutumu & A2, A3, A4, A7, A9, A11 \\
& Aile tutumu & A1, A6, A11 \\
\hline Materyal & Zekâ oyunları & A4,A5, \\
& Basılı materyal & A6, A10 \\
& Öğretmenin imkanlarına dayalı & A2, A7, A10, A11 \\
\hline
\end{tabular}


Tablo 4'de görüldüğü üzere gerçekleştirilen sentezleme çalışması sonunda destek eğitim odası hizmetinde var olan duruma ilişkin 4 ana kategori ortaya çıkmıştır. Bu kategoriler; fiziksel koşullar, verilen eğitim, tutum ve materyalden oluşmaktadır. Bu çalışmaya dahil edilen araştırmalarda ulaşılan bulguların analizi sonucunda DEO hizmetinde mevcut duruma ilişkin olarak ilk kategori fiziksel koşullar olarak belirlenmiştir. Bu kategori altında fiziksel koşulların uygun olup olmamasına ilişkin iki alt kategori ortaya çıkmıştır. Araştırmaya dahil edilen çalışmaların ikisinde fiziksel koşulların genel olarak uygunluğunun ön plana çıktığı görülmektedir. Aydın'ın (2015, s. 89) araştırmasında destek eğitim odasına ilişkin olarak “Ortalama büyüklüğü var ve yeterli olduğunu düşünüyorum.” alıntısı bu alt kategoriye örnek olarak gösterilebilir. Öte yandan incelenen araştırmaların önemli bir çoğunluğunda fiziksel koşulların yetersizliğine dikkat çekilmektedir. Araştırma bulgularında genel olarak belirli bir sınıftan çok müdür yardımcısı odası, rehberlik servisi, öğretmenler odası veya kütüphane gibi esas kullanım amacı farklı olan ortamlarda destek eğitim hizmetinin gerçekleştirdiği vurgulanmaktadırlar. Örnek olarak farklı araştırmalardan alınan aşağıdaki alıntılar gösterilebilir. Pemik (2017; s. 61) “Belli bir odamız yok neresi boşsa orayı kullanıyoruz. Çocuklar için çok rahat edecekleri bir ortam yok”. Başka bir araştırmada (Kaptan, 2019; s. 40 ) ise; "Sadece adı olan ama görünürde olmayan bir odanın fiziksel şartlarlyla ilgili olarak size ne söyleyebilirim ki. Biz bu uygulamayı öğretmenler odasında yapıyoruz.” sözleriyle destek eğitim uygulaması için odalarının olmadığını belirtmektedir. Benzer şekilde farklı bir araştırmada da destek eğitim odaları için ayrılan yerlerin kullanışsız mekanlar olduğu şu sözlerle "Bir kere şöyle sırf destek sınıfi olmuyor yani. Destek sınıfi okulda işte ben ne diyeyim, en ücra, ucube köşeler size veriliyor." (Dalga, 2019; s.114) vurgulanmaktadır.

Bu araştırmada DEO hizmetinde var olan duruma ilişkin ulaşılan ikinci kategori “verilen eğitim" olarak belirlenmiştir. Bu kategori altında destek eğitim odasında verilen eğitime ilişkin bulgulardan BEP, öğrenci ihtiyaçları odaklı, zekâ oyunları ve anlatıma dayalı olmak üzere dört alt kategori ortaya çıkmıştır. Araştırmaya dahil edilen tezlerde, destek eğitim odası sürecinde verilen eğitimde BEP'leri dikkate aldıkları görülmektedir. Nitekim Pesen (2019; s. 74) tarafından yapılan araştırmada "Öğrencinin özel durumu dikkate alınarak yıllık BEP planına göre belirlemekteyim” sözleri ile BEP’ten yararlanıldığını vurgulanmaktadır. Yine başka bir araştırmada da (Aydın, 2015; s. 96) “okul rehber öğretmenimiz bu konuda destek oluyor să̆ olsun, onun da yardımıyla BEP oluşturuyoruz" sözleri ile öğrencinin eğitim sürecinde BEP hazırlandığı belirtilmektedir. 
DEO hizmetleri kapsamında verilen eğitimde öğrencinin ihtiyaçlarının dikkate alındığ1 belirlenmiştir. Bu alt kategoriye ilişkin olarak Pesen (2019) araştırmasından “ Öğrenci okuma yazma sorunu yaşıyorsa okuma yazmaya yönelik çalışmalar yaparım. Matematikte sorun yaşıyorsa temel matematik kavramları üzerinde dururum" (s.74) alıntısı örnek verilebilir.

$\mathrm{Bu}$ araştırma kapsamında incelenen tezlerin ikisinde özellikle özel yetenekli öğrencilere yönelik DEO hizmetlerine ilişkin görüşler konu edinilmiştir. Bu araştırmaların bulgularında verilen eğitim kategorisine ilişkin olarak zekâ oyunları alt kategorisi ön plana çıkmaktadır. Nar '1n tezinde (2017) verilen eğitime ilişkin olarak "Matematik derslerine giriyorum. Sudoku, kendoku, abc gibi oyunlar oynatıyorum” (s.87) ve "Zekâ oyunlarına ă̆ırlık vermekteyim.” (s. 88 ) şeklinde alıntılar buna örnek verilebilir. Yine Pemik'in (2017) yaptığı araştırmada da benzer şekilde "Elimizde bir tek akıl oyunları vardı. Destek odada çocuklarla bunları oynadık." (s.54) sözleri ile eğitim sürecinde genellikle zekâ oyunlarına ağırlık verildiğini vurgulanmaktadir.

İncelenen araştırmalarda destek eğitim odalarında verilen eğitimde genel olarak anlatım tekniğinin kullanıldığı görülmektedir. Bu bulguya ilişkin olarak Tamas’ın (2017; s. 47) çalışmasında bir katılımcı anlatım yöntemini kullandığını belirtmektedir. Yine benzer şekilde Pesen’in (2019) çalışmasında da “Kullanımının kolay olmasından dolayı anlatım yoluyla öğretim yapıyorum.”(s.77) sözleri ile anlatım tekniğini kolay olmasından dolayı tercih edildiği vurgulanmaktadir.

DEO hizmetinde mevcut duruma ilişkin olarak bir başka kategori tutum olarak belirlenmiştir. Bu kategori altında öğrenci ve veli tutumları olmak üzere iki alt kategori ortaya çıkmıştır. Araştırmaya dahil edilen çalışmalarda genellikle öğrencilerin olumlu tutumu ön plana çıktığı görülmektedir. Çağlar'ın (2017; s.66) araştırmasında öğrenci tutumlarına ilişkin olarak “Destek ĕgitim odası derslerini dört gözle bekliyorlar. Hatta zil çalar çalmaz ögretmenler odasının kapısında 'hadi hocam seni bekliyorum' diyen bir öğrencim bile var.” sözleri ile öğrencilerin heyecanı vurgulanmaktadır. Filik (2019) tarafından yapılan araştırmada da öğrencilerin olumlu tutumu “...Sadece kendisiyle ilgilenildiği için sınıf ortamına göre derse karşı daha ilgili” (s. 49) sözleri ile destek eğitim odalarında öğrenciler ile bire bir ilgilenmesi ile açıklanmaktadır. Araştırma bulgularında velilerin de genellikle olumlu bir tutum sergiledikleri belirtilmektedir. Örneğin Semiz'in (2018) yaptığı araştırmada “....Tabi onlarda işin iyi yönde seyrettiğini görünce çocukları gönderme konusunda istekli. İlk başlarda hiç istekli olmamalarına rağmen şimdi göndermek için can atıyorlar.”(s.60) sözleri ile öğrencilerin 
eğitimindeki olumlu gelişmenin velilerin tutumunu olumlu yönde değiştirdiği vurgulanmaktadır.

DEO hizmetinde mevcut duruma ilişkin olarak son kategori ise kullanılan materyal kategorisidir. Bu kategori altında zekâ oyunları, basılı materyaller ve öğretmen çabasına dayalı olmak üzere üç alt kategori ortaya çıkmıştır. Araştırmaya dahil edilen tezlerden özel yetenekli öğrencilere yönelik faaliyetlere odaklanan çalışmalarda destek eğitim odalarında genellikle zekâ oyunları kullanıldığı ön plana çıkmaktadır. Nar (2017) tarafında yapılan araştırmada bu durum “Destek ĕgitim odalarında ă̆ırlıkla zekâ oyunları bulunmakta.” ( s. 101) sözleri ile açıklanmaktadır. Özel yetenekliler dışında kalan özel gereksinimli öğrencilere ilişkin araştırmalarda ise öğretim faaliyetlerinde genellikle basılı materyaller olan kitapların yoğun kullanıldığı vurgulanmaktadır. Dalga'nın (2019) yaptığı araştırmada derslerde okuma setlerinin kullandığı şu sözlerle “Genelde ilk birinci sınıflarda kullanılan okuma setleri oluyor. Biz onlarla çalışma yapıyoruz.” (s.92) belirtilmektedir. Araştırma bulgularında öğretim amaçlı kullanılan materyallerin genel olarak öğretmenler tarafindan kendi çabaları ile temin edildiği ön plana çıkmaktadır. Aydın (2015) tarafından gerçekleştirilen çalışmada öğretmenlerden biri destek eğitim odasında kullandığı materyalleri kırtasiyelerden rica ederek aldığını belirtmektedir (s.48). Bu durum benzer şekilde Filik (2019) tarafından yapılan araştırmada da şu şekilde “...destek ĕgitimin verildiği ögretim alanının öğrencilerin ihtiyaçlarını karşılaması öğretmenin dışardan getirdiği materyallerle sınırlı." (S. 51) vurgulanmaktadır.

\section{DEO Hizmetinde Karşılaşılan Sorunlar}

Araştırmada sürecinde incelenen tezlerden, DEO hizmetinde karşılaşılan sorunları ortaya koyan bulgulardan elde edilmiş kategori ve alt kategoriler Tablo 5'de verilmiştir.

Tablo 5. Karşılan Sorunlara ilişkin Bulgulara Yönelik Kategoriler ve Alt kategoriler

\begin{tabular}{lll}
\hline Kategori & Alt Kategori & İlgili Çalışma \\
\hline Fiziksel Koşullar & Fiziksel şartların yetersizliği & A2, A4, A5, A9, A10,A11, A12, \\
\hline Verilen Eğitim & Öğretmen eğitimi & A1, A3, A4, A9, A11 \\
& Aile desteği & A2, A4, A8, A10 \\
& BEP'e uyulmaması & A1, A6, \\
\hline Planlama & Tanılama sorunları & A5, A11, \\
& Ders saati sorunları & A1, A2, A3, A4, A7, A8, A9, A10 \\
& Yönetmelikte belirsizlikler & A1, A3, A6, A10 \\
& İşirliği sorunları & A1, A2, A7, A8 \\
& Devamsızlık & A4, A6, A11 \\
\hline Tutum & Etiketleme kaygıs1 & A1, A8, A10 \\
& İsteksizlik & A1, A3, A8, A10 \\
\hline Materyal & Yetersiz Materyal & A2, A4, A5, A8, A9, A10, A11, A12 \\
\hline
\end{tabular}

Tablo 5'de görüldüğü üzere gerçekleştirilen sentezleme çalışması sonunda destek eğitim odalarında karşılaşılan sorunlara ilişkin 5 ana kategori ortaya çıkmıştır. Bu kategoriler; fiziksel 
koşullar, verilen eğitim, tutum ve materyalden oluşmaktadır. Araştırmada yapılan analiz sonucunda DEO hizmetinde yaşanan sorunlara ilişkin olarak ilk kategori fiziksel koşullar olarak belirlenmiştir. Bu kategori altında fiziksel koşulların yetersizliği alt kategorisi ortaya çıkmıştır. Araştırmada değerlendirilen tezlerde genel olarak fiziksel koşulların yetersiz olduğuna ilişkin görüşlerin ön plana çıktığı görülmektedir. Örnek olarak Dalga (2019; s. 114) tarafindan yapılan çalışmada fiziksel koşulların yetersizliği “Karşılaştığımız en büyük sorunumuz sınıf mesela. Biz şu anda burada 2 ögretmen ders yapıyoruz.” şeklinde açıklamaktadır.

Destek eğitim odalarında karşılaşılan sorunlar bağlamında ikinci kategori olarak eğitim faaliyetleri başlığı altında öğretmen eğitimi, aile desteği ve BEP'e uyulmaması alt kategorileri belirlenmiştir. Araştırma sürecinde incelenen tezlerde destek eğitim odasında görev alan öğretmenlerin eğitimine ilişkin kaygılar dikkat çekmektedir. Genel olarak öğretmenlerin alan bilgileri konusunda yetkin olmalarına rağmen özel gereksinimli öğrencilerle ilgili bilgi ve tecrübe eksiklikleri vurgulanmaktadır. Araştırmalarda bu durum “Bu ögrencilere nasıl davranılır bilmiyoruz. Özel eğitim çocuklarına destek eğitim odası hizmeti vermek için önce bize destek eğitim şart.” (Çağlar, 2017; s.62) şeklinde vurgulanmaktadır. Benzer şekilde Kaptan (2019) öğretmenlerin eğitim ihtiyacı “... kendi alandaki mesleki bilgileri yeterlidir ama özel eğitimle ilgili yani bu çocuklara kullanılacak yöntemler, teknikler, materyaller eğitim araçları noktasında eksiklerin olduğunu düşünüyorum.” ( s.58) şeklinde bulgulamıştır.

Özel gereksinimli öğrencilerin eğitiminde başarı için velilerin sürece aktif katılımı önemli bir işleve sahiptir. Bu araştırma kapsamında incelenen yüksek lisans tezlerinde de velilerin eğitim sürecine katılımının yetersizliği ön plana çıkan bir başka alt kategori olarak belirlenmiştir. Pesen (2019; s. 93) tezinde velilerin eğitim sürecine katılımına ilişkin olarak " $B u$ süreçte öğrenci velisinin katılımını yetersiz buluyorum. ... Veli gönüllü olarak aktif olmalıdır.” bulgusuna yer vermiştir.

Destek eğitim odasında yürütülen eğitim faaliyetlerinde öğrenciler için hazırlanan bireyselleştirilmiş eğitim programının uygulanması gerekmektedir. İncelenen araştırmalarda bu konuda sorun yaşandığı ve BEP'lerin uygulanmasında sorunlar yaşandığı görülmektedir. Semiz (2018) tarafından gerçekleştirilen araştırmaya "Valla o planları genelde internet ortamından alıyoruz. Ama uyabiliyor muyuz uyamıyoruz.” (s. 50) ş̧eklinde yansıyan bulgu süreçte bu bağlamda yaşananları özetlemektedir.

DEO hizmetinde karşılaşılan sorunlar bağlamında üçüncü kategori olarak planlama başlığı altında tanılama sorunları, ders saatleri sorunları, yönetmelikte belirsizlikler, işbirliği sorunları ve devamsızlık alt kategorileri belirlenmiştir. Destek eğitim odasında öğrencilerin 
eğitim alması için öncelikle özel gereksinimli olarak tanılanması gerekmektedir. Bu süreçte yaşanan tanılama sorunları, öğrencilerin eğitim sürecini olumsuz etkileyebilir. İncelenen çalışmalarda yanlış tanılama sonuçlarına ilişkin bilgiler görülmektedir. Örneğin özel yetenekli olarak tanılanması gereken öğrencinin zihin yetersizliği tanısı alması dikkat çekmektedir (Pemik, 2017; s. 69). Bazı öğretmenler ise destek eğitim odasına devam eden öğrencilerine daha ağır düzeyde tanı konulması gerektiğini "Teorikte hafif düzey olarak belirlenen ögrrencimin aslında daha ă̆ır düzeyde olduğu kanaatindeyim.” (Filik,2019; s.58) sözleri ile belirtmektedir.

Destek eğitim odasında öğrencinin kaç ders saati eğitim alacağı yine planlamada yaşanan sorunlar arasında görülmektedir. Bu konuda her ne kadar yönetmelikte haftalık ders saatinin \% 40’’nı geçmeyecek şekilde bir ibare (MEB, 2020) varsa da katılımcılar ders saatlerinin farklı nedenlerden dolayı yeterli olmadığını belirtmektedirler. Örneğin Dalga (2019; s. 115) ve Semiz (2018) tarafından ders saatlerinin yetersizliği öğrenci sayısının fazla olması ile açıklanmaktadır. Örnek alıntı olarak “Burada öğrenci sayısı fazla olduğu için çocuklara düşen saat de az. Yani mesela bir çocuğa üç saat bazen iki saat bile ancak düşebiliyor.”(Dalga, 2019; s. 115) ile sorun fazla öğrenci sayısına bağlanmaktadır.

İncelenen araştırmalarda planlama kategorisi altında dile getirilen bir başka sorun alanı ise yönetmelikten kaynaklı sorunlardır. Özel eğitim kapsamında olmasından dolayı destek eğitim odasının açılması ve yürütülecek faaliyetlere ilişkin düzenlemeler Özel Eğitim Hizmetleri Yönetmeliği’nde yer almaktadır. Araştırmalarda hem uygulama süreci hem de ek ders ödemeleri benzeri maddi konularda yönetmelikteki çelişki ve muğlaklıklara dikkat çekilmektedir. Örneğin Çağlar (2017) tarafından gerçekleştirilen araştırmaya ders saatlerine ilişkin çelişki “12 saate kadar verilebilir maddesi var yönetmelikte ama 10 ögrenci destek eğitim odasında eğitim alacaksa 12 saat nasıl alabilir. Uygulama ile teori çelişiyor.” (s.61) şeklinde yansımaktadır.

Özel eğitimde paydaşlar arası işbirliği önemli bir yere sahiptir. Özellikle farklı ortamlarda eğitim alan özel gereksinimli öğrencilerin eğitimlerinin etkili ve başarılı olmasında aile, sınıf öğretmeni ve destek eğitim odası öğretmeni arasında etkili bir işbirliği gerekmektedir. İncelenen araştırmalarda destek eğitim odası uygulaması sürecinde hem sınıf öğretmenleri ile hem de aile ile işbirliğinin etkili yürütülemediğine ilişkin bulgular dikkat çekmektedir. Konuyla ilgili olarak örneğin “...sınıf öğretmenleri ile çok iyi iletişimler kuramıyorum. Yani çünkü onlar çok fazla zaman ayırmak istemiyorlar.” (Dalga, 2019; s.116) bulgusu ile sınıf öğretmenlerinin sürece yeterli desteği sağlamadıkları belirtilmektedir. Bir başka araştırmada ise aile ile işbirliği 
ve sürece ailenin etkin katılımının yeterli düzeyde olmaması, okulun velilerinin sosyal ve ekonomik gelişmişlik düzeyine bağlanmaktadır (Filik, 2019; s. 53).

DEO hizmetinin yürütülmesi sürecinde yaşanan sorunlar bağlamında planlama kategorisi altında belirlenen son alt kategori devamsızlıktır. İncelenen tezlerde öğrencilerin farklı nedenlerden kaynaklı devamsızlık yaptıkları görülmektedir. Örneğin özel yetenekli öğrencilerin devamsızlık nedeni olarak okul dışında farklı kurslara da devam ediyor olmaları gösterilmektedir (Nar, 2017; s. 96). Filik’in (2019) gerçekleştirdiği araştırmada devamsızlıkların süreci ciddi anlamda etkilediği şu şekilde “Devamsızlık durumu çalışmanın seyrini çok olumsuz etkiliyor. Planlanan çalışmalar gerektiği süre ve ölçüde yapılamadiğında kazanılan becerileri de olumsuz etkiliyor.” (s.60) vurgulanmaktadır.

DEO hizmetinde karşılaşılan sorunlar bağlamında dördüncü kategori olarak tutum başlığı altında etiketleme ve isteksizlik alt kategorileri belirlenmiştir. Etiketleme, öğrencilerin destek eğitim odasına devam etmelerinden dolayı arkadaşları tarafından olumsuz tutumlarla karşılaşmaları veya karşılaşacaklarına yönelik algıları olarak tanımlanabilir. Özel gereksinimli çocukların akranları tarafından olumsuz tutumla karşılaşmaları bu öğrencilerin destek eğitim odasına gitme isteklerini olumsuz etkileyebilmektedir. Nitekim incelenen araştırmalarda da bu durumu destekleyen görüşler dikkat çekmektedir. Dalga (2019) tarafından gerçekleştirilen araştırmada bu durum "İşte çocukların kaynaştırma olan çocukları etiketlemesi. Sen anlamıyorsun, sen bu işi bilmiyorsun da gidiyorsun öğrenmeye tepkileri oluyor.” (s.110) şeklinde yansımıştır. Aynı zamanda destek eğitim odasına devam eden öğrencide de kendisine karşı olumsuz bir algı oluşabilmektedir. Örnek olarak “Öğrenciyi arkadaşlarından ayırdığımız için kendini sorunlu öğrenci profilinde görebilir.” (Pesen, 2019; s. 90) bulgusu ile bu durum vurgulanmaktadır. Öğrencilerin destek eğitim odasına gitmekte isteksiz olması bazen yoğun ders yükünden (Pesen, 2019; s, 89 ) bazen de arkadaşlarından ayrılmak istememekten (Çağlar, 2017; s. 80) kaynaklanabilmektedir.

DEO hizmetinde karşılaşılan sorunlar bağlamında son kategori olarak materyal kategorisi altında materyal eksikliği alt kategorisi belirlenmiştir. Özel gereksinimli çocukların eğitiminde, öğrencinin ihtiyaçları doğrultusunda materyallerin kullanılması, eğitim sürecinin başarısında etkin rol oynamaktadır. Destek eğitim odalarında farklı yetersizlik grubundan öğrenciler eğitim aldıkları için materyal temininde zorluk yaşandığı, araştırmalarda vurgulanmaktadır. Nitekim sorunlar bağlamında katılımcılar tarafından farklı araştırmalarda bu durum belirtilmektedir. Örneğin Dalga (2019) tarafından yapılan çalışmada materyal eksikliği “En büyük sorunum materyal. Çocukların seviyesinde bir araç gereç kitap eksikliği kaynak 
eksikliğimiz var." Şeklinde bulgulanmıştır (s. 112). Başka bir araştırmada ise öğrencilerin farklı özelliklerinden dolayı ihtiyaç duyulan materyallerin temininde sorunlar yaşandığı belirtilmektedir (Kaptan, 2019; s. 54).

\section{DEO Hizmetine ilişkin Öneriler}

Araştırma sürecinde incelenen tezlerden, destek eğitim odası hizmetinin iyileştirilmesine yönelik sunulan önerileri ortaya koyan bulgulardan elde edilmiş kategori ve alt kategoriler Tablo 6'da verilmiştir.

Tablo 6. Önerilere ilişkin Bulgulara Yönelik Kategoriler ve Alt kategoriler

\begin{tabular}{lll}
\hline Kategori & Alt Kategori & İlgili Çalışma \\
\hline Fiziksel Koşullar & Fiziksel düzenleme & A1, A2, A3, A4, A6, A8, A9, A10, A11 \\
\hline Verilen Eğitim & Veli desteği & A2, A7, A11 \\
& Öğrenci odaklı eğitim & A3, A8 \\
& Öğretmen eğitimi & A3, A4, A5, A6, A7, A8, A9, A10, A11 \\
\hline Planlama & Öğretmen seçimi & A1, A7, A10 \\
& Ders saatlerinin düzenlenmesi & A2, A3, A4, A7, A8, A9, A11 \\
& İşbirliğinin arttırılması & A1, A2, A7, A8, A11, \\
\hline Materyal & Materyal desteği sağlanmas1 & A2, A3, A8, A9, A10, A11 \\
\hline
\end{tabular}

Yapılan sentezleme çalışması sonucunda Tablo 6'da görüldüğü üzere DEO hizmetinin iyileştirilmesine ilişkin öneri olarak 4 ana kategori ortaya çıkmıştır. Bu kategoriler; fiziksel koşullar, verilen eğitim, planlama ve materyal başlıklarından oluşmaktadır. Bu kategorilere ait alt kategoriler ve kategorilere kaynaklık eden çalışmalardan doğrudan alıntı örnekleri izleyen paragraflarda sunulmuştur.

İncelenen araştırmalarda sıklıkla vurgulanan konulardan biri destek eğitim odalarının fiziksel olarak yetersizliğidir. Buna paralel olarak katılımcılar tarafından sunulan önerilerde de fiziksel koşulların iyileştirilmesi önemli bir yer tutmaktadır. Araştırmalarda sadece zorunlu olduğu için okuldaki herhangi bir ortamın destek eğitim odası olarak kullanılmaması gerektiği, özel eğitime uygun odaların açılması “Okullarda kütüphane veya boş sınıflar yerine gerçekten destek ĕgitim odaları açılmalıdır.” (Filik, 2019; s. 56) vurgulamaktadır. Ayrıca sınıfın fiziksel donanımının, farklı gereksinime sahip öğrencilere hitap edecek şekilde olması gerektiği “...öğrencinin rahat edeceği şekilde donatılmalı” (Kış, 2013; s. 57) ve “...odanın içerisinde her türlü düzenin, sandalyeden dolaplara kadar tahtaya kadar yer zemine kadar her şey bu öğrenciye göre düzenlenmesi gerektiğini düşünüyorum.” (Aydın, 2015; s.102) belirtmektedirler.

İncelenen tezlerden hareketle DEO hizmetinin iyileştirilmesi için sunulan önerilerden oluşturulan ikinci kategori verilen eğitim başlığı altında aile desteği, öğrenci odaklı eğitim ve öğretmen eğitimi alt kategorilerinden oluşturulmuştur. Araştırmalarda eğitim sürecine velilerin daha aktif katılımının başarı için gerekliliği “...veli desteği ile başarı sağlanacă̆ını 
düşünüyorum.” (Filik, 2019; s. 56) sözleri ile açıklanmaktadırlar. Velilerin sürece katılımı için özellikle velilerin bilinçlendirilmesi gerektiği ve bunun için okul ve bakanlığın daha fazla inisiyatif alması gerektiği “ ... gerek okul olarak gerek milli eğitim olarak, veliler de biraz bilinçlendirilmeli, bizim burada yaptı̆̆ımız eğitim evde biraz daha fazla desteklense belki daha fazla ilerleme kaydedilecek." (Aydın, 2015; s. 156) vurgulanmaktadır.

Verilen eğitim kategorisi altında yer alan bir başka alt kategori öğrenci odaklı alt kategorisidir. Araştırma bulgularında yer alan önerilerde destek eğitim odalarında sürdürülen eğitim faaliyetlerinde özel gereksinimli öğrencilerin özellik ve ihtiyaçlarının sürecin odağında yer alması gerektiği belirtilmektedir. Örneğin Çağlar (2017; s. 72) tarafından gerçekleştirilen araştırmada “Öğrenci odaklı olarak destek eğitim odası uygulaması düşünülürse başarılı olacağına inanıyorum." sözleri ile bu durum vurgulanmaktadır. Yine başka bir çalışmada (Pesen, 2019) eğitim sürecinde kazanımların özel gereksinimli öğrenciye göre belirlenmesi gerektiği belirtilmektedir (s. 1010). Destek eğitim odasının işlevselliğini ve başarısını arttırmada verilen eğitim kategorisinde özellikle ön plana çıkan önerilerin öğretmen eğitimi ile ilgili oldukları görülmektedir. Genel olarak bulgular incelendiğinde öğretmenlerin özellikle özel eğitim konusunda eğitim almaları gerektiği vurgulanmaktadır. Örneğin eğitimin alan uzmanlar tarafindan verilmesi gerektiği “Bu çocuklar için okuduğunuz diploma yetmiyor aslında. Öğretmenlerin gerekirse mesela altı aylık, bir yıllık uzmanlardan ĕgitim alması çok gerekli” şeklinde bulgulara yansımaktadır (Dalga, 2019; s. 119).

İncelenen yüksek lisans tezlerinde önerilerin yoğun olarak yapıldı̆̆ olarak planlama dikkat çekmektedir. Planlama kategorisi altında öğretmen seçimi, ders saatlerinin düzenlenmesi ve işbirliğinin sağlanması alt kategorileri yer almaktadır. Öğretmen seçimine yönelik planlamaya ilişkin olarak özellikle belirli standartların olması gerektiği belirtilmektedir. Örneğin görevlendirme süreci ve olması gerekene yönelik olarak "Şimdi şöyle oluyor, her sene norm kadro fazlası olan öğretmen ya da emekli olacak diye düşünen ögretmenler genelde tercih ediliyor destek sınıfi için... Sınıf öğretmenlerinin içinden bir kadrolaşma olabilir.” (Dalga,2019; s.118) tespiti dikkat çekmektedir. Destek eğitim odasında öğretmen görevlendirmesi konusunda bir başka öneri olarak öğretmenin özel eğitim konusunda bilgi ve deneyime sahip olması gelmektedir. Nitekim bu öneriye örnek olarak “Destek odasında eğitim veren arkadaşın alan bilgisinin yeterli olması lazım, özel ĕgitim öğretmeni olması lazım” (Kış,2013; s.52) bulgusu verilebilir. Planlama konusunda araştırma bulgularında öneri olarak belirtilen konulardan biri de ders saatlerinin düzenlenmesine yöneliktir. Bu konuda bazı tezlerde derslerin okul saati dışında verilmesi ve öğrencilerin kendi sınıftaki derslerinden geri 
kalmaması gerektiği belirtilmektedir. Örneğin Kaptan'ın araştırmasına (2019) bu öneri “Bu uygulama hafta sonlarına, okul saati dışına yayılsa süre konusundaki yetersizliklerin ortadan kalkacă̆ını düşünüyorum” (s.43) şeklinde belirtilmektedir. Ayrıca derslerin belirli bir saatte yapılmaması eleştirilmekte ve "Çocuğun belli bir zamana odaklanması ve o zaman da gelip katılması gerekiyor diye düşünüyorum.” (Aydın, 2015; s.105) sözleri ders saatlerinin önceden planlanması gerektiği vurgulamaktadırlar. DEO hizmetleri kapsamında yürütülen eğitim faaliyetlerinin başarılı olması için incelenen araştırmalarda sunulan önerilerden biri de paydaşlar arası uyum ve işbirliğidir. Araştırma bulguları, destek eğitim odasında görev yapan öğretmenlerin özellikle sınıf öğretmeni ve veliler ile işbirliği yapması yönünde önerilerde bulunulduğunu göstermektedir. Pesen (2019) tarafından gerçekleştirilen araştırmada süreçte öğretmenler arasında aktif bir diyaloğun olması gerektiği “Bütün öğretmenleri bir araya gelerek çocuğun ilerleyişi hakkında diyalog halinde olmalılar. Sınıf ögretmeni ve rehber öğretmeni işbirliği halinde olmalıdır.” (s. 101) şeklinde vurgulanmaktadır.

DEO hizmetinin daha işlevsel olması için geliştirilen öneriler arasında sıklıkla vurgulanan alanlardan biri de materyal desteğine yöneliktir. Destek eğitim odaları özel gereksinimi olan farklı öğrencilerin eğitim aldığı ortamlar olmalarından dolayı, içinde bu çocukların eğitiminde kullanılabilecek farklı materyallerin bulundurulması gerekmektedir. Araştırmalarda da genellikle bu ihtiyaçlara dikkat çekildiği görülmektedir. Bu konuda Dalga (2019) tarafından yapılan çalışmada "Farklı seviyede öğrenciler geliyor. Onların hepsine cevap verebilecek şekilde çok farklı materyallerin hazır olması lazım” (s. 118) önerisi örnek olarak verilebilir. Yine benzer şekilde Filik (2019) tarafından yapılan araştırmada da "Bu ögrenciler için özel materyaller olmalı ve ortam buna göre düzenlenmelidir.”(s. 55) bulgusu ile öğrencilerin ihtiyaçlarının farklılığını vurgulamaktadır.

\section{Tartışma, Sonuç ve Öneriler}

DEO hizmetlerine ilişkin katılımcı görüşlerini konu edinen lisansüstü eğitim tezlerinin incelendiği bu araştırmada çoğunlukla öğretmen görüşlerine odaklanan araştırmalar belirli kriterler ile analiz edilerek bütüncül bir bakış açısı sağlanmaya çalışılmıştır. Yapılan analiz sonucunda üç (3) ana kategori ortaya çıkmıştır. Bunlar; (a) DEO hizmetinde var olan durum, (b) karşılaşılan sorunlar ve (c) DEO hizmetinin iyileştirilmesine yönelik öneriler şeklinde olmuştur. $\mathrm{Bu}$ ana kategorilerin altında genel hatlarıyla fiziksel koşullar, verilen eğitim, planlama, tutum ve materyal başlıklarında alt kategoriler oluşturulmuştur.

Araştırma sonunda destek eğitim odasının varlığına yönelik memnuniyet dikkat çekmektedir. Açıkçası tezlerde süreçte yaşanan sorunlar daha fazla ön plana çıkarılmasına 
rağmen DEO hizmetine yönelik memnuniyet ilk etapta bir çelişki olarak değerlendirilebilir. Farklı çalışmalarda da benzer şekilde kaynaştırma ve DEO hizmetlerine olumlu yaklaşımlar görülmektedir (Diken ve Batu, 2015; Ünal, 2008). DEO hizmetlerine yönelik olumlu yaklaşım aslında uygulama sürecinin iyi işlemesinden çok, özel gereksinimli öğrencilere bu tarz “ayrıcalıklı" hizmetlerin sunulması gerektiğine ilişkin bir yargıdan kaynaklı olabilir. Özel gereksinimli öğrencilerin genel eğitim sınıflarındaki eğitim imkânlarından yeterince yararlanamamasına rağmen, destek eğitim odasında bire bir eğitim alabilmeleri, bu hizmetlerin olumlu değerlendirilmesini sağlamaktadır. Nitekim özellikle kaynaştırma eğitimi üzerine yapılan farklı araştırmalarda (Demir ve Açar, 2011; Gök, 2013; Güleryüz, 2014; Sadioğlu, Bilgin, Batu ve Oksal, 2013) genel eğitim sınıflarında özel gereksinimli öğrencilere yeterli düzeyde eğitim sunulamadığı vurgulanmaktadır. Yani bu sonuç, özünde her ne kadar uygulama sürecinde ciddi sorunlar yaşandığı görülse de, özel gereksinimli öğrenciler ile daha yakın şekilde ilgilenilmesine imkan sağlamasından dolayı DEO hizmetlerine karşı olumlu bir tutumun oluşmasını açıklamaktadır.

Araştırma sonucunda her üç kategori altında en fazla, fiziksel koşullar alt kategorisi dikkat çekmektedir. Öncelikle DEO hizmetinin verildiği ortamların fiziksel koşulları, buralarda görülen sorunlar ve iyileştirmelerine yönelik önerilerde benzer sonuçlar görülmektedir. Araştırmaların çoğunluğunda okullarda DEO olarak kullanılan ortamların ihtiyaçları karşılamada yetersiz kaldıkları belirtilmektedir. Kaynaştırma ve destek eğitim odaları üzerine yapılan farklı çalışmalarda da ilk etapta sorun olarak fiziksel koşulların bulgu olarak sunulduğu görülmektedir (Batu vd., 2018; Çevik ve Yağc1, 2017; Eripek, 2004; Nar ve Tortop, 2017; Sucuoğlu, 2004; Tunalı Erkan, 2018; Yazıcıŏlu, 2020). Fiziksel koşullar denilince sadece eğitimin verildiği sınıf değil aynı zamanda bu sınıfın 1sı, 1şık, temizlik, büyüklüğü gibi özelliklerinin de göz önüne alınması gerekmektedir. Nitekim MEB (2017), DEO hizmetinin yürütüleceği ortamların, fiziki şartlarının eğitime uygun ve öğrencilerin kolay ulaşılabileceği mekanlar olmasını önermektedir. Hatta eğitim öğretim açısından elverişsiz ortamlarda özel eğitim sınıfı ile destek eğitim odası düzenlemesi yapılmayacağı MEB Kaynaştırma/Bütünleştirme Yoluyla Eğitim Uygulamaları Genelgesi'nde (2017) vurgulanmaktadır. Yine Deshponde (2013) DEO olarak kullanılacak mekânın asgari şartlarının bireysel ve grup eğitimine uygun olması gerektiğini belirtmektedir. Fakat bu açık hükümlere rağmen, incelenen araştırmalarda, DEO hizmetleri için kullanılan ortamların seçiminde gerekli hassasiyetin gösterilmediği görülmektedir. $\mathrm{Bu}$ durum farklı nedenlerden kaynaklanabilir. Öncelikle okullarında özel gereksinimli öğrenci bulunan okullar, uygun ortam olmasa da DEO 
açmaya teşvik edilmektedirler. Bu durumda okul idareleri bazen atıl olan ve eğitim için çok uygun olmayan ortamları veya kütüphane, öğretmenler odası, rehber öğretmen odası gibi mekanları bu amaçla kullanıma açmak zorunda kalmaktadırlar. $\mathrm{Bu}$ durum aslında MEB tarafından da bilinmektedir. Nitekim Milli Eğitim Bakanlığı tarafından yayımlanan Destek Eğitim Odaları Kılavuzu'nda da “fizikî şartları nedeniyle destek eğitim odası açılamayan okullarda il/ilçe millî eğitim müdürlüklerinin onayı doğrultusunda fen laboratuvarları, resim atölyeleri, müzik odaları vb. uygun alanların destek eğitim odası olarak kullanılabileceği” ifadesine yer verilmiştir (MEB, 2015).

Her ne kadar okulda DEO açılmasında, MEB uygun ortamın olmasını öncelikli şart olarak görmese de, incelenen araştırmalarda bu durum önemsenmektedir. DEO hizmetinin daha verimli olmasında öncelikli olarak uygun fiziksel koşulların sağlanması gerektiğini vurgulanmaktadır. MEB Özel Eğitim Hizmetleri Yönetmeliği’nde DEO; Tam zamanlı kaynaştırma/bütünleştirme yoluyla eğitimlerine devam eden öğrenciler ile özel yetenekli öğrencilere ihtiyaç duydukları alanlarda destek eğitim hizmetleri verilmesi için düzenlenmiş ortam olarak tanımlanmaktadır (MEB, 2020). Bu bağlamda düşünüldüğünde, amacı dışında DEO olarak kullanılan idari odalar, öğretmenler odası vb. mekanlarda verilen DEO hizmetinin amacına hizmet edemeyeceği düşünülmektedir. Son yıllarda MEB tarafindan DEO’ların fiziksel şartlarına yönelik olumsuz geri bildirimlerin de etkisiyle yeni standartlara sahip nitelikli DEO'ları hizmete açtıkları görülmektedir. Nitekim MEB tarafindan tasarlanan yeni standartlardaki DEO ların 2020 yılı başında sayısı 400’e çıkarılmıştır (Hürriyet Gazetesi, 2020). Şüphesiz bu tarz yüksek standartlara sahip DEO'ların yaygınlaşması, okullarda daha nitelikli özel eğitim hizmetleri sunulmasına katkı sunacaktır.

İncelenen tezlerde fiziksel koşullarla bağlantılı olarak DEO’ların donanımı ve kullanılan materyaller ile ilgili sonuçların ön plana çıktığı söylenebilir. İncelenen araştırmalarda materyal ve donanım ile ilgili genelde sorun ve öneri bağlamında görüş belirtildiği görülmektedir. Çalışmalarda genel olarak var olan DEO’ların gerekli donanıma sahip olmadıkları ve özel gereksinimli öğrencilerin eğitimlerinde ihtiyaç duyulan materyallerin yeterli düzeyde bulunmadığı belirtilmektedir. Var olan materyallerin ise genellikle öğretmenlerin kendi çabaları ile sağlandığı vurgulanmaktadır. Alanyazında farklı araştırmalarda (Çevik ve Yağcı, 2017; Demir ve Açar, 2011; Sadioğlu vd., 2013; Tunalı Erkan, 2018; Yazıcığlu, 2020), benzer şekilde donanım ve materyal anlamında eksiklikler belirtilmektedir. Bu durum özel gereksinimli öğrencilerin eğitiminin başarısı bağlamında değerlendirildiğinde önemli bir eksiklik olarak değerlendirilmektedir. Nitekim kaynaştırma eğitiminin başarısı için, özel 
gereksinimli öğrencilerin akademik, sosyal ve davranış gelişimini destekleyici materyallerle öğretimin yapılması gerektiği çeşitli araştırmacılar (Glomb ve Morgan, 1991; Kargın, Güldenoğlu ve Şahin, 2010; Yılmaz ve Batu, 2016) tarafından vurgulanmaktadır. DEO ile ilgili yönetmelik ve kılavuzlar incelendiğinde farklı eğitim kademelerinde açılan DEO’larda bulunması gereken materyallerin detaylı bir şekilde açıklandığı görülmektedir (MEB, 2015). Fakat incelenen araştırmalarda bu konuda okulların gerekli hassasiyeti göstermediği ön plana çıkmaktadır. Son yıllarda yeni standartlara göre açılan DEO'ların sayısının artması bu konuda var olan sorunların çözümünde de etkili olacağı değerlendirilmektedir.

Araştırma sonucunda dikkat çeken konulardan biri de DEO hizmeti kapsamında verilen eğitimlerdir. Bu konuda ortak fikir olarak, verilen eğitimin etkili ve kalıcı olabilmesi için öğrencinin ihtiyaçları doğrultusunda yetkin öğretmenler tarafından verilmesinin ön plana çıktığı söylenebilir. Fakat halihazırda yürütülen süreçte bu şartların sağlanmasında sorunlar yaşandığı belirtilmektedir. Sonuçlar, öğretmenlerin her ne kadar kendi branşlarında yetkin olsalar da özel eğitim konusunda eksikliklerinin olduğunu göstermektedir. Ayrıca eğitim sürecinde BEP planlarının hazırlanması ve uygulanmasında da sorunların yaşandığı incelenen araştırmalara yansıdığı görülmektedir. Oysa DEO'da verilecek eğitim ile ilgili olarak MEB'de (2020) öğrencilerin performans düzeylerinin referans alınması ve buna paralel olarak öncelikle özel eğitim öğretmenlerinden görevlendirme yapılması gerektiği belirtilmektedir. Öğretmen seçiminde sorunların olması daha çok okulların iç dinamikleri ile açıklanabileceği düşünülmektedir. İncelen araştırmaların birinde vurgulandığı gibi (Dalga, 2019; s. 118), DEO’ya öğretmen seçiminde uzmanlıktan önce farklı kriterler işe koşulabilmektedir.

Araştırma sonucunda DEO'da verilen eğitime yönelik iyileştirme önerileri arasında öğretmenlere yönelik özellikle özel eğitim konusunda hizmetiçi eğitimler verilmesi ön plana çıkmaktadır. Kaynaştırma ve DEO bağlamında yapılan birçok çalışmada (Avramidis ve Norwich, 2002; Demirezen ve Akhan, 2016; Kargın, Acarlar ve Sucuoğlu, 2003; Saraç ve Çolak, 2012; Önder, 2007; Tortop ve Dinçer, 2016; Y1lmaz ve Batu, 2016), benzer şekilde öğretmen eğitiminin yetersizliği ve öğretmen eğitimine yönelik öneriler yer almaktadır. Yapılan çalışmalarda öğretmenlerin genel olarak eğitim sürecinin planlamasında ve yürütülmesinde önemli bir işleve sahip bireysel eğitim programının hazırlanması ve uygulanmasında gereken özenin gösterilmediği vurgulanmaktadır (Güven, 2021; Yazçayır ve Gürgür, 2021). Yine öğretmenlerin özel gereksinimli öğrencilerin eğitimi konusunda gerekli uyarlamaları yapma ve alan bilgisi konularında yeterli düzeyde olmadıkları vurgulanmaktadır (Batmaz ve Çermik, 2019). Hem bu araştırmanın sonuçları hem de alanyazında yer alan araştırmaların sonuçları 
DEO’da görev alacak öğretmenlerin özel gereksinimli öğrencilerin eğitimi konusunda ciddi düzeyde eğitime ihtiyaç duyduğunu ortaya koymaktadır. Her ne kadar Kaynaştırma/Bütünleştirme Yoluyla Eğitim Uygulamaları başlıklı Genelge'de (2017) öğretmenlerin, DEO’da eğitim vermeye başlamadan önce özel eğitime ilişkin hizmet içi eğitim alacakları belirtilse de, verilen bu hizmet içi eğitimlerin işlevsel olmadığı söylenebilir. Buradan hareketle öncelikle DEO’da özel eğitim öğretmenlerinin görevlendirilmesinin gerekliği ortaya çıkmaktadır. Fakat özel eğitim öğretmenlerinin görevlendirilemeyeceği durumlarda, görevlendirme sürecinde iletişim becerileri güçlü, yeniliğe açık, özel eğitim veya alanında yüksek lisans yapmış ve DEO'da görevlendirme konusunda gönüllü olan öğretmenlerin seçimine öncelik verilmesi önerilebilir. Ayrıca hazırlanan hizmet içi eğitimlerde teorik bilgiden çok uygulama temelli programlara ağırlık verilmesi ve özel gereksinimli öğrencilerin eğitiminde etkililiği kanıtlanmış bilimsel dayanaklı uygulamalara yer verilmelidir. Son olarak eğitim fakültelerinde öğretmen adaylarına verilen özel eğitim derslerinin içeriğinde DEO hizmet sürecinin etkili olabilmesi için gerekli düzenlemelerin yapılması gerekmektedir.

Araştırmada öne çıkan bir başka sonuç paydaşlar arası işbirliğinin gerekliliğine ilişkindir. Aslan (2019) tarafından gerçekleştirilen araştırmada paydaşlar arasında işbirliği olduğu belirtilmektedir. İncelenen diğer araştırmalarda ise genellikle DEO paydaşları arasında gerekli işbirliğinin sağlanamadığı görülmektedir. Oysa özel eğitimde paydaşlar arası işbirliği önemli bir yere sahiptir. Özellikle aile, sınıf öğretmeni ve destek eğitim odası öğretmeni arasında etkili bir işbirliği gerekmektedir. İncelenen araştırmalarda destek eğitim odası uygulaması sürecinde hem sınıf öğretmenleri ile hem de aile ile işbirliğinin etkili yürütülemediğine ilişkin sonuçlar dikkat çekmektedir. Alanyazında kaynaştırma uygulamalarının başarılı olabilmesi için ön koşul olarak paydaşlar arası işbirliğinin olması ve paydaşların etkin katılımı ile sürecin bir ekip tarafından yürütülmesi önerilmektedir (Öpengin, 2018; van der Meulen vd., 2014; Zigmond, Kloo veVolonino, 2009). Yine alanyazında ailelerin sürece etkin katılımı ve hem sınıf öğretmeni hem de DEO öğretmeni ile işbirliği yapmasının özel gereksinimli öğrencilerin eğitimine olumlu katkı sunacağı belirtilmektedir (Demirezen ve Akhan, 2016; Gürgür, Akçamete ve Vuran, 2005; Heward, 2013; Sorani-Villanueva, McMahon, Crouch ve Keys, 2014). Buradan hareketle öncelikle DEO'da eğitim sürecini planlama ve yürütmede sorumluluğu bulunan okul yönetiminin paydaşlar arasında işbirliğini sağlaması gerekmektedir. $\mathrm{Bu}$ amaçla belirli aralıklarla öğrenci ve DEO sürecini değerlendirmeleri için ilgili paydaşların bir araya gelip karşılıklı görüşlerini paylaşacakları toplantıların düzenlenmesi önerilebilir. 
Son olarak araştırmada DEO sürecinin planlanması aşamasında özellikle ders saatleri ve ders süreleri konusunda sorunlar yaşandığı görülmektedir. Bazı araştırmalarda destek eğitimin okul saatleri dışında verilmesinin daha işlevsel olacağı belirtilmektedir. Ayrıca DEO’da geçirilen ders saatinin yetersiz olduğu, verilen eğitimin etkili olabilmesi için ders saatlerinin arttırılması gerektiği vurgulanmaktadır. MEB Özel Eğitim Hizmetleri Yönetmeliği'nde (2020) DEO ders saatlerine ilişkin olarak 25. Maddede öğrencilerin haftalık ders saatinin \%40'nı aşmayacak şekilde planlanması gerektiği belirtilmektedir. Yani haftalık 30 saat ders yapılan bir okulda özel gereksinimli bir öğrenci 12 saate kadar DEO hizmetinden yararlanabilir. Fakat genel olarak okullarda bir tane destek eğitim odası açılmakta ve öğrenci sayısı fazla olunca her öğrenci ortalama iki-üç saat DEO'dan yararlanabilmektedir (Çağlar, 2017; Dalga, 2019). Öte yandan her ne kadar yönetmelikte okul saatleri dişında da DEO eğitiminin yapılabileceği belirtilse de, hem öğrencinin hem de öğretmenin okul saatleri sonrasında eğitime devam etme konusunda fiziksel ve zihinsel olarak zorlanacakları düşünülmektedir. DEO saatlerinin planlanmasında herkes için geçerli bir doğru karar vermek zor olacaktır. Burada okulun, öğretmenin ve öğrencinin özgün şartları dikkate alınarak yönetmelikte sunulan esneklik doğrultusunda bireysel kararların alınmasının daha doğru bir tutum olacağı düşünülmektedir.

Sonuç olarak DEO hizmeti ile ilgili görüşlere odaklanan tezlerde yer alan bulguların sentezlendiği bu çalışmada genel olarak DEO hizmetine yönelik olumlu bir bakış açısının var olduğu söylenebilir. Paydaşların DEO hizmetinin var olması gerektiği konusunda hem fikir oldukları görülmektedir. Öte yandan sürecin işleyişini olumsuz etkileyen ciddi sorunların varlığı dikkat çekmektedir. Burada temel sorun yönetmeliklerde DEO hizmetine ilişkin koşullar olumlu şekilde düzenlenmiş olmasına rağmen, uygulamada farklı nedenlerden kaynaklı olarak olumsuzlukların daha fazla ön plana çıkmasıdır. Hem bu araştırmada hem de ilgili ulusal alanyazında öne çıkan sorunlar ve çözüm önerileri aslında etkili bir DEO hizmetinin nasıl olması gerektiği konusunda net bir resim çizmektedir. Yapılması gereken başta Milli Eğitim Bakanlığı olmak üzere ilgili paydaşların DEO hizmetinin etkili ve gerekli olduğuna inanmalarıdır. Son yıllarda özellikle donanımlı DEO’ların sayısındaki artış bu konuda umut verici olarak değerlendirilmektedir. Fiziksel ve donanım olarak uygun DEO'ların sayısının artması, alanyazında sorun olarak ifade edilen konuların önemli bir bölümünü çözecektir. Ayrıca okullarda açılan DEO’ların öğrenci programlarının düzenlenmesinde yerel şartlar dikkate alınarak yapılacak planlamalar, sunulan hizmetlerin kalitesini arttıracaktır. Fakat paydaşların süreci işbirliği içinde uygun şekilde planlayabilmesi için kaynaştırma eğitimi 
kapsamında destek eğitim odalarının işleyişine ilişkin mevzuat hakkında gerekli bilgilendirme çalışmalarının yapılmasının yararlı olacağı düşünülmektedir. Özellikle DEO’ların işleyiş süreci, BEP biriminin işleyişi, görevleri ve işbirliği konusunda tüm paydaşların süreç içerisinde bilgilendirilmeleri gerekmektedir. Son olarak öğretmenlere, üniversitelerin özel eğitim bölümlerinin işbirliği ile özel eğitim konusunda uygulamaya dayalı verilecek eğitimin, destek eğitim odası hizmetinin gelişimi ve başarısına katkı sunacağı düşünülmektedir.

$\mathrm{Bu}$ çalışmada ortaya çıkan sonuçlara göre ileri araştırmalara yönelik de çeşitli öneriler sunulabilir. Yapılan bu araştırma ile paydaş görüşlerine dayalı olarak DEO hizmetinin ne durumda olduğunun somut olarak ortaya konulmuş olduğu düşünülmektedir. Buradan hareketle ileriki araştırmalarda var olan durumu ortaya koymaya yönelik durum ve betimsel araştırmalar yerine özellikle sorunların işlevsel çözüm yollarına odaklanan yol gösterici çalışmaların yapılması önerilmektedir. Durum çalışmaları olarak yeni faaliyete geçirilen destek eğitim odalarının etkililiği yine araştırma konusu olarak önerilebilir. Son olarak özellikle eylem araştırması olarak tasarlanan öğretmen eğitimi odaklı araştırmaların yapılması önerilmektedir.

\section{Makalenin Bilimdeki Konumu}

\section{Eğitim Bilimleri Bölümü/Özel Eğitim, Destek Eğitim Odası}

\section{Makalenin Bilimdeki Özgünlüğü}

$\mathrm{Bu}$ makalede, destek eğitim odaları üzerine görüşlere dayalı yapılan araştırmalar sentezlenerek bulgularının bütüncül bir değerlendirmesi sunulmuştur. Araştırmanın destek eğitim odalarındaki mevcut durumda özellikle yaşanılan sorunları ortaya koymasının, yapılacak yeni araştırmalara ufuk açacağı düşünülmektedir.

\section{Kaynaklar}

Akay, E. (2015). Kaynaştırma ortamındaki işitme engelli öğrencilere destek eğitim odasında uygulanan Türkçe etkinliklerinin incelenmesi. Journal of Education \& Special Education Technology, 1(1), 1-14.

Akay, E. ve Gürgür, H. (2018). Kaynaştırma uygulamalarında destek özel eğitim hizmeti sunan öğretmenin mesleki gelişimi: Mentörlük. Eğitimde Nitel Araştırmalar Dergisi, 6(1), 936.

Aslan, S. T. (2019). Kaynaştırma eğitimine devam eden işitme yetersizliği olan öğrencilere verilen destek ĕgitim hizmetlerinin ögretmen görüşlerine göre dĕgerlendirilmesi (Yayınlanmamış Yüksek Lisans Tezi). Necmettin Erbakan Üniversitesi Eğitim Bilimleri Enstitüsü, Konya. 
Aydın, A. (2015). Zihinsel yetersizliğe sahip öğrencilere destek ĕ̆itim odasında verilen eğitim hizmetlerine ilişkin öğretmen görüşleri (Yayınlanmamış Yüksek lisans tezi). Abant İzzet Baysal Üniversitesi Eğitim Bilimleri Enstitüsü, Bolu.

Avramidis, E., \& Norwich, B. (2002). Teachers' attitudes towards integration/inclusion: A review of the literature. European Journal of Special Needs Education, 17(2), 129-147.

Bakkaloğlu, H., Yılmaz, B., Altun Könez, N. ve Yalçın, G. (2018). What do the research about preschool inclusion in Turkey tell us? Inonu University Journal of the Faculty of Education, 19(1), 119-150.

Batu, E. S., Cüre, G., Nar, S., Gövercin, D. ve Keskin, M. (2018). Türkiye'de ilkokul ve ortaokullarda yapılan kaynaştırma araştırmalarının gözden geçirilmesi. Ankara Üniversitesi Ĕgitim Bilimleri Fakültesi Özel Ĕ̆itim Dergisi, 19(3), 577-614.

Bedur, S., Bilgiç, N. ve Taşlıdere, E. (2015) . Özel (üstün) yetenekli öğrencilere sunulan destek eğitim hizmetlerinin değerlendirilmesi. Hasan Ali Yücel Eğitim Fakültesi Dergisi, 121(23), 159-175.

Cox, J. \& Daniel, N. (1984). The pull-out model. G/C/T, 34, 55-61.

Creswell, J. W. (2014). Educational research: planning, conducting and evaluating quanitative and qualitative Research. Upper saddle river, New Jersey: Pearson Education, Inc.

Çağlar, N. (2016). İlköğretim kurumlarındaki destek ĕgitim odası uygulamasına ilişkin okul yöneticileri ve öğretmenlerin görüşlerinin incelenmesi (Yayınlanmamış Yüksek lisans tezi). Gazi Üniversitesi Eğitim Bilimleri Enstitüsü, Ankara.

Çevik, M. ve Yağcı, A. (2017). Destek eğitim odalarına ilişkin idareci ve sınıf öğretmenlerinin görüşleri: Karaman ili örneği. The Journal of Academic Social Science Studies, 58(2), 6579.

Dalga, R.A. (2019). Destek eğitim odasında görev alan ögrretmenlerin özel öğrenme güçlüğ̈̈ olan ögrrencilerle yaptıkları eğitim öğretime ilişkin görüş ve önerileri (Yayınlanmamış Yüksek Lisans Tezi). Marmara Üniversitesi Eğitim Bilimleri Enstitüsü, İstanbul.

Demir, M. K. ve Açar, S. (2011). Kaynaştırma eğitimi konusunda tecrübeli sınıf öğretmenlerinin görüşleri. Kastamonu Eğitim Dergisi, 19(3), 719-732.

Demir, S. ve Avcu, Y. E. (2018). Özel yetenekli öğrencilere yönelik destek eğitim odalarına ilişkin öğretmen görüşleri. YYÜ Eğitim Fakültesi Dergisi, 15(1), 156-185.

Demirezen, S. ve Akhan, N. E. (2016). Sosyal bilgiler öğretmenlerinin kaynaştırma uygulamalarına ilişskin görüşleri. Abant İzzet Baysal Üniversitesi Ĕ̈itim Fakültesi Dergisi, 16, (USBES Özel Sayı II), 1206-1223. 
Deniz, E. Ve Çoban, A. (2019). Kaynaştırma eğitimine ilişkin öğretmen görüşleri, Electronic Journal of Social Sciences,70(18), 734-761.

DePape, A., \& Lindsay, S. (2016). Lived experiences from the perspective of individuals with autism spectrum disorder: A qualitative meta-synthesis. Focus on Autism and Other Developmental Disabilities, 31(1), 60-71.

Diken, İ. H. ve Batu, E. S. (2015).Kaynaştırmaya giriş. İ.H. Diken (Ed.), İlköğretimde kaynaştırma, içinde (s.2-24). Ankara:Pegem Akademi.

Dinçer, S. ve Tortop, H. S. (2016). Destek eğitim odalarında üstün/üstün yetenekli öğrencilerle çalışan sınıf öğretmenlerinin uygulama hakkındaki görüşleri. Üstün Yetenekliler Eğitimi ve Araştırmaları Dergisi, 4(2), 11-28.

Eripek, S. (2004). Türkiye'de zihin engelli çocukların kaynaştırılmalarına ilişkin olarak yapılan araştırmaların gözden geçirilmesi. Ankara Üniversitesi Eğitim Bilimleri Fakültesi Özel Ĕ̌itim Dergisi, 5(2) 25-32.

Farrell, M. (2010). Debating Special Education. London: Routledge.

Filik, R. (2019). Sınıf öğretmenlerinin destek eğitim odaları hakkındaki görüşlerinin belirlenmesi (Yayınlanmamış Yüksek Lisans Tezi). Necmettin Erbakan Üniversitesi Eğitim Bilimleri Enstitüsü, Konya.

Friend, M., \& Bursuck, W. M. (2012). Including students with special needs: A practical guide for classroom teachers. Boston MA: Pearson.

Gay, L. R., Mills, G. E., \& Airasian, P. (2012). Educational research: Competencies for analysis and application (10th ed.). New Jersey: Pearson Merrill Prentice Hall.

Gök, R. (2013). Kaynaştırma eğitimi öğrencisi bulunan ilkokul sinıf öğretmenlerinin sınıf yönetiminde karşılaştıkları zorluklar ve bu zorluklarla başa çıkma yöntemleri (Yayınlanmamış Yüksek lisans tezi). Akdeniz Üniversitesi Eğitim Bilimleri Enstitüsü, Antalya.

Gökdemir, F., \& Dolgun, G. (2020). Writing material \& method section in qualitative, quantitative, systematic review, meta-analysis, and meta-synthesis studies. Archives of Health Science and Research, 7(2), 189-195.

Glomb, K., \& Morgan, D. P. (1991). Resource room teachers use of strategies that promote the success of handicapped students in regular classrooms. The Journal of Special Education, 25(2), 221-235.

Gubbins, E. J. (2013). Cognitive and affective outcomes of pull-out programs: Knowns and unknows. In C. M. Callahan \& H. L. Hertberg-Davis (Eds.), Fundamentals of gifted 
YYÜ Eğitim Fakültesi Dergisi (YYU Journal of Education Faculty), 2021;18(2)633-663,http://efdergi.yyu.edu.tr,

education: Considering multiple perspectives (pp. 176-188). New York, NY: Routledge.

Güleryüz, B. (2014). Sınıf ögretmenlerinin ve sınıf öğretmeni adaylarının kaynaştırma eğitimine ilişkin görüşlerinin belirlenmesi (Yayınlanmamış Yüksek lisans tezi). Bülent Ecevit Üniversitesi Sosyal Bilimler Enstitüsü, Zonguldak.

Gürgür, H. ve Hasanoğlu -Yazçayır, G. (2019). Türkiye'de kaynaştırma eğitimine yönelik öğretmenlerin görüşlerine odaklanılmış lisansüstü eğitim tezlerinin sentezlenmesi: meta-etnografik bir çalışma. Eğitimde Nitel Araştırmalar Dergisi, 7(2), 845-872.

Gürgür, H., Akçamete, G. ve Vuran, S. (2005). Teachers opinions about implementation of curriculum of elementary schools for children with hearing impaired. Eğitim Bilimleri ve Uygulama, 4(7), 69-91.

Güven, D. (2021). Destek eğitim odası öğretmeninin rol ve sorumlulukları. Trakya Eğitim Dergisi, 11(1), 450-463.

Heward, W. L. (2013). Exceptional children: An introduction to special education. Boston: Pearson

Hürriyet Eğitim. (2020, 23 Ocak). Destek eğitim odalarının sayısı 400’e çıktı. Hürriyet. Erişim adresi:https://www.hurriyet.com.tr/egitim/destek-egitim-odalarinin-sayisi-400e-cikti-

$\underline{41426126}$

Kale, M. ve Demir, S. (2017). İlkokullardaki destek oda eğitimin Türkçe ve matematik dersleri başarısı üzerindeki etkisinin incelenmesi. Türk Bilim Araştırmaları Vakfı Dergisi, 10(4), 47-57.

Kaptan, Ö. (2019). Kaynaştırma okullarındaki özel gereksinimli bireylere destek ĕgitim odasında ĕgitim veren öğretmenlerin süreç içerisinde karşılaştıkları güçlüklerin belirlenmesi (Yayınlanmamış Yüksek Lisans Tezi). Necmettin Erbakan Üniversitesi Eğitim Bilimleri Enstitüsü, Konya.

Kargın, T., Acarlar, F. ve Sucuoğlu, B. (2003). Öğretmen, yönetici ve anne-babaların kaynaştırma uygulamalarına ilişkin görüşlerinin belirlenmesi. Özel Eğitim Dergisi, 4(2), 55-77.

Kargın, T., Güldenoğlu, B. ve Şahin, F. (2010). Genel eğitim sınıflarındaki özel gereksinimli öğrenciler için yapılması gereken uyarlamalara ilişkin sınıf öğretmenlerinin görüşlerinin incelenmesi. Kuram ve Uygulamada Ĕgitim Bilimleri, 10(4), 2381-2414. 
Kış, H. (2013). Destek eğitim odalarındaki uygulamalara ilişkin rehber ögretmenler ve özel eğitim sınıf ögretmenlerinin görüşleri (Yayınlanmamış Yüksek Lisans Tezi). Abant İzzet Baysal Üniversitesi Eğitim Bilimleri Enstitüsü, Bolu.

Matthews, D., \& Kitchen, J. (2007). Perceptions of students and teachers in public secondary schools. Gifted Child Quarterly, 5(3), 256-270.

MEB. (1997). 573 Sayılı Özel Eğitim Hakkında Kanun Hükmünde Kararname. https://orgm.meb.gov.tr/meb_iys_dosyalar/2012_10/10111011_ozel_egitim_kanun_hu kmunda_kararname.pdf adresinden edinilmiştir.

MEB. (2015). Destek Eğitim Odası Klavuzu. Ankara: MEB Özel Eğitim ve Rehberlik Hizmetleri Genel Müdürlüğü.

MEB. (2017). Kaynaştırma/bütünleştirme yoluyla eğitim uygulamaları genelgesi. https://orgm.meb.gov.tr/meb_iys_dosyalar/2017_09/21112929_kaynastirma_genelge.p df adresinden edinilmiştir.

MEB. (2020). Özel Ĕ̈itim Hizmetleri Yönetmeliği. http://orgm.meb.gov.tr/meb_iys_dosyalar/2020_06/24163215_ozel_eYitim_yonetmeli Yi_son_hali.pdf adresinden edinilmiştir.

Mengi, A. (2020). Engelli bireylerin gözüyle özel eğitim ve rehabilitasyon merkezlerindeki eğitim durumlarının incelenmesi. Manas Sosyal Araştırmalar Dergisi, 9(1), 19-33.

Metin, Ş. (2013). Türkiye'de okul öncesinde kaynaştırmaya ilişkin yapılan çalışmaların incelenmesi. Bayburt Eğitim Fakültesi Dergisi, 8(1), 159-185.

Mittler, P. (2000). Working towards inclusive education: Social contexts. London: David FultonPublishers.

Nar, B. (2017). Üstün / özel yetenekli öğrencilere yönelik destek eğitim odası uygulaması: sınıf öğretmenlerinin öz yeterlikleri ve görüşleri (Yayınlanmamış Yüksek Lisans Tezi). İstanbul Aydın Üniversitesi Sosyal Bilimleri Enstitüsü, İstanbul.

Nar, B., ve Tortop, H. S. (2017). Türkiye'de özel/üstün yetenekli öğrenciler için destek eğitim odası uygulaması: sorunlar ve öneriler. Aydın Üniversitesi Eğitim Fakültesi Dergisi, 3(1), 83-97.

Osin, L. \& Lesgold, A. (1996). A proposal for the reengineering of the educational system. Review of educational research, 66, 621-656.

Önder, M. (2007). Sınıf öğretmenlerinin zihin engelli kaynaştırma öğrencileri için sınıf içinde yaptıkları ögretimsel uygulamaların belirlenmesi (Yayınlanmamış Yüksek lisans tezi). Abant İzzet Baysal Üniversitesi Eğitim Bilimleri Enstitüsü, Bolu. 
Öpengin, E. (2018). Illkokul düzeyindeki üstün yetenekli öğrencilere yönelik destek eğitim odasının yürütülmesinde karşılaşılan sorunlar ve sorunlara yönelik çözüm müdahaleleri (Yayımlanmamış Doktora Tezi). Anadolu Üniversitesi Eğitim Bilimleri Enstitüsü, Eskişehir.

Pemik, K. (2017). Üstün yetenekli öğrencilere destek odasında verilen ĕgitime ilişkin okul yöneticilerinin ve öğretmenlerin görüşleri (Yayınlanmamış Yüksek Lisans Tezi). Marmara Üniversitesi Eğitim Bilimleri Enstitüsü, İstanbul.

Pesen, H. (2019). Destek ĕgitim odası uygulamalarına ilişkin öğretmen görüşlerinin incelenmesi (Yayınlanmamış Yüksek Lisans Tezi). Siirt Üniversitesi, Siirt.

Rogers, K. B. (2002). Re-forming gifted education: Matching the program to the child. Scottsdale, AZ: Great Potential Press.

Sadioğlu, Ö., Bilgin, A., Batu, S., \& Oksal, A. (2013). Sınıf öğretmenlerinin kaynaştırmaya ilişkin sorunları, beklentileri ve önerileri. Kuram ve Uygulamada Eğitim Bilimleri, 13(3), 1743-1765.

Saraç, T. ve Çolak, A. (2012). Kaynaştırma uygulamaları sürecinde ilköğretim sınıf öğretmenlerinin karşılaştıkları sorunlara ilişkin görüş ve önerileri. Mersin Üniversitesi Ĕ̈itim Fakültesi Dergisi, 8, 13-28.

Semiz, N. (2018). Özel gereksinimli öğrencilere yönelik destek ĕgitim odası uygulamalarına ilişkin ögretmen ve aile görüşlerinin belirlenmesi (Yayımlanmamış Yüksek Lisans Tezi). Abant İzzet Baysal Üniversitesi Eğitim Bilimleri Enstitüsü, Bolu.

Sorani-Villanueva, S., McMahon, S. D., Crouch, R., \& Keys, C. B. (2014). School problems and solutions for students with disabilities: A qualitative examination. Journal of Prevention\&Intervention in the Community, 42, 58-71.

Sucuoğlu, B. (2004). Türkiye'de kaynaştırma uygulamaları: Yayınlar, araştırmalar (19802005). Ankara Üniversitesi Eğitim Bilimleri Fakültesi Özel Ĕ̆itim Dergisi, 5(2), 15-23.

Tamas, G. (2019). Sınıf öğretmenleri ve velilerin destek ĕgitim odası uygulamalarına ilişkin görüşleri (Yayınlanmamış Yüksek Lisans Tezi). Bayburt Üniversitesi Sosyal Bilimler Enstitüsü, Bayburt.

Tunalı-Erkan, D. (2018).Ortaöğretim kurumlarındaki destek eğitim odası uygulamasına ilişkin öğretmen görüşleri. Uluslararası Liderlik Eğitimi Dergisi, 2(2), 17-30.

Ünal, H. (2008). Birlikte ĕgitim ortamındaki zihinsel yetersizlikten etkilenmiş öğrencilere destek ĕgitim odasında verilen destek eğitimin etkililiği (Yayınlanmamış Yüksek Lisans Tezi). Gazi Üniversitesi Eğitim Bilimleri Enstitüsü, Ankara. 
YYÜ Eğitim Fakültesi Dergisi (YYU Journal of Education Faculty), 2021;18(2)633-663,http://efdergi.yyu.edu.tr,

Van der Meulen, R. T., van der Bruggen, C. O., Spilt, J. L., Verouden, J., Berkhout, M., \& Bögels, S. M. (2014). The pullout program Day a Week School for gifted children: Effects on social-emotional and academic functioning. Child Youth Care Forum, 43, 287-314.

Yazçayır, G. ve Gürgür, H. (2021). Examination of inclusive education and resource room service in a preschool: Examination of inclusive education and resource room service. International Journal of Curriculum and Instruction, 13(1), 870-892.

Yazıcıoğlu, T. (2018). Kaynaştırma uygulamalarının tarihsel süreci ve Türkiye'de uygulanan kaynaştırma modelleri. Nevşehir Hacı Bektaş Veli Üniversitesi SBE Dergisi, 8(1), 92110.

Y1lmaz, K. (2021). Sosyal bilimlerde ve eğitim bilimlerinde sistematik derleme, meta değerlendirme ve bibliyometrik analizler. Manas Sosyal Araştırmalar Dergisi, 10(2), 1457-1490.

Yılmaz, E. ve Batu, E. S. (2016). Farklı branştan ilkokul öğretmenlerinin bireyselleştirilmiş eğitim programı, yasal düzenlemeler ve kaynaştırma uygulamaları hakkındaki görüşleri. Ankara Üniversitesi Eğitim Bilimleri Fakültesi Özel Eğitim Dergisi, 17(3), 247-268.

Zigmond, N., Kloo, A., \& Volonino, V. (2009). What, where, and how? Special education in the climate of full inclusion, Exceptionality, 17(4), 189-204. 


\section{Extended Abstrack}

\section{Introduction}

Inclusive education in Turkey are carried out in the form of full-time or part-time special education classes. The resource room (RR) is frequently used as a choice in schools where fulltime inclusion is provided. RR is widely accepted as a pull-out program ((Friend \& Bursuck, 2012; Heward, 2013; Gubbins, 2013). It is referred settings created through special tools and materials with the aim of assisting the children with special needs to benefit from the education services within the scope of inclusive education (MEB, 2020).

The popularity of RR's in the education of students with special needs has also increased the academic interest in this educational environment. A considerable number of theses and articles has been written in Turkey about RR especially in recent years. Accordingly, there is a growing need to merge and synthesize these studies from a holistic perspective. Examining the researches on RR's will contribute to reaching comprehensive information about the researches made so far. Based on these thoughts, the purpose of the present research is to examine the postgraduate theses focusing on the opinions of stakeholder about RR's.

\section{Methodology}

This research has been designed in line with systematic review in order to examine postgraduate theses employing interview technique. The process includes a systematic review of qualitative research literature with analysis and synthesis of research findings to produce a new understanding of the phenomena. A search using the keyword of "Resource Room" was undertaken at the Databases of National Thesis Center of the Council of Higher Education. In first stage 36 thesis related to RR determined. Then the thesis chosen by the criteria that is getting opinions of participant related to RR. The process of synthesizing findings from the twelve chosen thesis was undertaken by identifying categories in the combined data. The analysis involved generation of initial categories and subsuming initial themes into cluster categories.

\section{Findings and Discussion}

In this study, it was aimed to examine the postgraduate education theses on the opinions of the participants about the RR. Three (3) main categories emerged as a result of the analysis performed at the end of the study process. These are; (a) the current situation regarding the RR, (b) the problems regarding the RR, and (c) the suggestions to increase the quality of the RR. Under these main categories, sub-categories were formed under the headings of physical conditions, education, planning, attitude and material. 
According to findings of the evaluated theses, the satisfaction seen among the participants regarding the existence of the RR application. Similarly, in different studies, it is seen that stakeholders find inclusion and RR services useful and necessary (Diken \& Batu, 2015; Ünal, 2008). Participants' positive thoughts about RR services may actually be due to a judgment that such "privileged" services should be provided to students with special needs rather than their liking of the implementation process.

As a result of the systematic review, it can be said that the most common issue under all three category is the findings related to physical conditions. Participants of most of the thesis state that the physical environments used as RR in schools are insufficient to meet the needs. In different studies on inclusion and RR, it is seen that insufficient physical conditions are presented as the first problem too (Batu, et al, 2018; Çevik \& Yağcı, 2017; Eripek, 2004; Nar \& Tortop, 2017; Sucuoğlu, 2004; Tunalı Erkan, 2018; Yazıcıŏlu, 2020). Participants emphasize that appropriate physical conditions should be provided for the efficiency of the RR services.

In the studies examined, most of the participant state that RR do not furnished with necessary equipment and the materials needed in the education of special students are not at a sufficient level. It is emphasized that the existing materials are usually provided by teachers' own efforts. When this situation is evaluated in the context of the success of the education of students with special needs, it is considered as an important deficiency. As a matter of fact, it is emphasized by various researchers (Glomb \& Morgan, 1991; Kargın, Güldenoğlu, \& Şahin, 2010; Y1lmaz \& Batu, 2016) that education should be done with materials that support the academic, social and behavioral development of students with special needs for the success of inclusive education.

One of the subjects that seen as problematic was the education provided within the scope of the RR service. As a common opinion on this issue is that in order for the effective and permanent education, it should be given by competent teachers in line with the needs of the student. Participants emphasize that although the teachers are competent in their own branches, they lack of experience in special education. In the investigated studies, providing in-service trainings for teachers, especially on special education, comes to the fore among the improvement suggestions for the education given in the RR.

One of the important finding is related to cooperation among stakeholders. It is seen that there is not a proper cooperation between the RR stakeholders. However, in special education, an effective cooperation between the family, the classroom teacher and the RR teacher is a 
necessity. From this point of view, it is recommended to organize meetings where stakeholders related to the RR process come together and share their opinions in order to ensure cooperation among stakeholders.

The results of the study showed that there are problems in the planning of the RR process, especially in terms of course hours and course durations. Some of the participants stated that it would be more functional to provide support education outside of school hours. In addition, some participants emphasized that the course hours spent in the RR were insufficient, so the course hours should be increased for an effective education. It will be difficult to make the right decision for satisfy everyone when planning RR hours. It should be recommended that every school may take individual decisions in planning of the RR hours by considering the specific conditions of their school, teachers and students.

As a result, the prominent problems and solution suggestions both in this research and in the relevant national literature actually show how an effective RR service should be. Increasing the number of the RR which have proper physical conditions and suitable materials will solve a significant part of the issues expressed as problems in the literature. In addition, when if planning the RR process, the local conditions of the schools should be to be taking into account, it will increase the quality of the services provided. Finally, it is thought that the practical training to be given to teachers on special education in cooperation with the special education departments of universities will contribute to the development and success of RR.

With this study, it is thought that the state of RR services has been demonstrated concretely based on stakeholder opinions. However, it is recommended to conduct studies focusing on functional solutions to problems encountered rather than descriptive studies to reveal the existing situation in future studies. 